\title{
Proximate composition and changes in muscle proteins of dried salted abo (Otolithes ruber)
}

\author{
1,2, ${ }^{*}$ Avila, T.N., ${ }^{2}$ Bigueja, M.C., ${ }^{2}$ Bradecina, R.G., ${ }^{3}$ Mendoza, Jr., A.B., ${ }^{1,3}$ Canon, K.L. and \\ ${ }^{1}$ Kubota, S. \\ ${ }^{1}$ Graduate School of Integrated Arts and Sciences, Kochi University, Kohasu Oko, Nankoku, Kochi 783- \\ 8505, Japan \\ ${ }^{2}$ Partido State University, Goa 4422, Camarines Sur, Philippines \\ ${ }^{3}$ Bicol University - Tabaco Campus, Tabaco City 4511, Albay, Philippines
}

\begin{abstract}
Article history:
Received: 13 March 2021

Received in revised form: 7

April 2021

Accepted: 18 June 2021

Available Online: 5 February 2022
\end{abstract}

\section{Keywords:}

Tigertooth croaker, Proximate composition, SDS-PAGE,

Mass spectrometry

\section{DOI:}

https://doi.org/10.26656/fr.2017.6(1).064

\begin{abstract}
Dried salted abo is a popular fishery product in San Miguel Bay (SMB), Philippines. However, the development of this food product has not been fully explored. In this study, the proximate composition and muscle protein profile of dried salted abo was investigated after confirming the molecular identification of abo found in SMB. Sequence analysis of 16S ribosomal RNA and cytochrome c oxidase subunit I genes suggested that abo in SMB could be Otolithes ruber. Abo fillets were brined in $4 \%, 8 \%$, and $12 \%$ salt concentrations (w/w) and sun-dried for 6 and 12 hrs. In both 6 hrs and 12 hrs drying time, moisture content decreased in samples brined with $12 \%$ salt, suggesting that the salt concentration could be lowered between $8-12 \%$ with 6 hrs drying time. Additionally, the proteolytic profiling by SDS-PAGE analysis detected 17 bands in the myofibrillar protein fraction. Subsequent mass spectrometry identified nine proteins, of which the myosin heavy chain, actin, and keratin were degraded while the other proteins remained stable. Moreover, at $12 \%$ salt concentration, changes in staining intensities in several proteins were observed at both 6 hrs and 12 hrs drying time. These findings revealed that the applied salting and drying conditions led to the degradation of myosin heavy chain and polymerization of actin, in addition to an overall alteration of protein profile, which could affect the texture of dried abo product. Overall, this study demonstrated molecular evidence for species identification of abo for the first time. The information on proximate composition and changes in the protein profile of dried salted abo obtained from this study could help the local dried fish industry develop high-quality dried abo products with low salt content.
\end{abstract}

\section{Introduction}

Among the top fish producing countries globally, the Philippines ranked ninth in 2017 with a total production of 4.125 million metric tons (FAO, 2019). Approximately $38 \%$ of the total catch is processed into dried fish products, and the Philippines is the secondlargest dried-salted fish producer in Southeast Asia (Gabriel and Alano-Budiao, 2015). Dried fish products are widely accepted for their taste, nutritional quality, availability, and low cost. In the typical Filipino diet, fish is considered the third major component, with mean oneday household food consumption of fish and fish products at $392 \mathrm{~g}$ contributing $11.5 \%$ of the total food intake. The per capita consumption of fish and fish products in the country in 2015 was estimated at $36.8 \mathrm{~kg} /$ year, whereas dried fish consumption was at $4.2 \mathrm{~kg} / \mathrm{year}$
(DOST-FNRI, 2016a).

The Bicol region, encompassing the south-eastern part of Luzon Island, is the second leading contributor in municipal or small-scale fisheries (DA-BFAR, 2019), and San Miguel Bay (SMB) is the most productive coastal fishing ground in the Bicol region (Bailey, 1982; Mines et al., 1982; Pomeroy and Pido, 1995). It is characterized as a large, shallow estuarine water body with a soft (muddy and sandy) substrate (Silvestre and Hilomen, 2004). Croakers, belonging to the Sciaenidae family, are abundant in estuarine areas and prefer to occupy the soft substrata (Lanzuela et al., 2020). One of the most abundant croakers inhabiting the bay is the locally known "abo." Abo is a commercially important regional resource in the Bicol region because its fisheries are among the leading industries in the bay (Lanzuela et 
al., 2020). Abo has been identified as a tigertooth croaker (Otolithes ruber) by morphometry and meristic characterization (Navaluna, 1982). However, the similar morphological characteristics of other croakers, such as "pagotpot" and "arakaak" found in SMB (Lim et al., 1995), often lead to confusion. Therefore, its species identification needs to be confirmed via molecular approaches.

The production of dried salted abo is a common practice around SMB. At present, the commercial dried abo is produced with a long drying time and brining at high concentration of salt, as highly dried, and highly salty abo products are popular and preferred by the market. However, Yater et al. (1982) previously reported that traditional drying procedures in SMB follow a long soaking period in a salt solution and a short drying time. Therefore, the previous major dried abo products also contain high salt but with high moisture content. The interest in highly salted dried products is gaining popularity among consumers despite the risk of high salt diets. It has been reported that the prevalence of elevated blood pressure in the Philippines is increasing, and the salt intake of adults is higher than the recommended amount by the World Health Organization (WHO) (DOST-FNRI, 2016b; Lasco et al., 2020), which could be attributed to the dietary habits of the Filipinos. The major source of sodium in the diet of Filipinos are contributed by the condiments added during cooking (salt, soy sauce, fish sauce, monosodium glutamate, etc.), accounting for $76.3 \%$ of the total sodium intake, whereas whole foods contributed only $23.7 \%$ (Lee, 2009; Batcagan-Abueg et al., 2013). However, the health promotion campaigns focused on the modifiable risk factors of hypertension, such as improving diet and exercise, are increasing the consumers' health consciousness; therefore, increasing demand for low-salt food is expected. It is speculated that the dried fish, a source of dietary sodium in the Filipino diet, could be a potential vehicle for salt reduction, and therefore, the knowledge of the chemical composition of a fish is essential for its product development (Bamwirire, 2006).

The proximate composition is an important aspect of fish quality that influences the keeping quality and technological characteristics of the fish (Islam et al., 2013). In traditionally sun-dried fishes, high moisture, lower crude protein values, ash, and crude lipid content were reported (Msusa et al., 2017; Patterson et al., 2018). In addition, several studies on dried salted fish investigating the effects of different salting methods on proximate composition have reported that by brine salting and dry salting, there was a considerable loss in moisture due to heavy uptake of salt and an increase in ash and protein contents (Martìnez-Alvarez and Gómez-
Guillén, 2006). Moreover, salting affects the conformation of muscle proteins and alters the water holding capacity and subsequent protein denaturation (Offer and Trinick, 1983).

Biochemical changes in fish myofibrillar proteins had been studied to introduce scientific quality control into the production of dried fish products. Structural changes in proteins as observed in the production of cross-linked myosin heavy chains in some cured and dried meats suggested its effects on the textural formation of dried meat (Ito et al., 1990; Tambo et al., 1992). Furthermore, sodium dodecyl sulfatepolyacrylamide gel electrophoresis (SDS-PAGE) analyses used to identify different muscle proteins have also revealed the changes in the protein pattern of salted fish (Thorarinsdottir et al., 2002; Sannaveerappa et al., 2004; Martìnez-Alvarez and Gómez-Guillén, 2006). However, the myofibrillar proteins involved in these changes during different processing conditions were only tentatively identified by molecular weight. None of the studies has reported the precise identification of the degraded proteins through advanced techniques, such as mass spectrometry.

Moreover, there has been no information on the chemical composition of abo to date. We hypothesized that the standardization of the drying processes, particularly salt concentration and drying time, and characterization of the chemical properties of dried abo could help develop the strategies to improve it as a foodstuff with low-salt content and high consumer acceptability. Therefore, the present study aimed to confirm the species of abo found in SMB through a molecular approach and characterize the dried salted abo in terms of its proximate composition and muscle protein profile.

\section{Materials and methods}

\subsection{Materials}

Fresh abo was purchased from the local fish market in Calabanga, Camarines Sur, around SMB, Philippines. Commercial dried abo was also obtained from a local retail market to serve as the reference product. Chemicals (analytical grade) used in all experiments were obtained from Nacalai Tesque, Inc. (Japan) or Thermo Fisher Scientific (USA).

\subsection{DNA extraction, polymerase chain reaction} amplification and sequencing analysis

Three individuals of the purchased fresh abo were randomly selected, and a small piece of pectoral fin tissue was excised from each individual and preserved in $95 \%$ ethanol. Approximately $50 \mathrm{mg}$ fin tissue was 
subjected to DNA extraction using DNeasy Blood and Tissue Kit (Qiagen, Hilden, Germany) following the manufacturer's protocols. The cytochrome c oxidase subunit I (COI) gene was amplified using universal primers CoxI $\quad$ Fish $\quad$ F2 (5'TCGACTAATCATAAAGATATCGGCAC-3') and CoxI Fish

(5'ACTTCAGGGTGACCGAAGAATCAGAA-3')

(Ward et al., 2005) and 5346F
(5'CTTAGTTAACAGCTAARCGC-3') and 6446R (5'GTRTCTACGTCTATTCCGAC-3'). Polymerase chain reaction (PCR) was performed in a $25 \mu \mathrm{L}$ reaction volume following the PCR conditions reported by Lo et al. (2017). The mitochondrial 16S rRNA gene was amplified using the primers 16SAR (5'CGCCTGTTTATCAAAAACAT-3') and 16SBR (5'CCGGTCTGAACTCAGATCACGT-3') (Palumbi et al., 2002) following the PCR conditions outlined by Lakra et al. (2009). The PCR products were visualized by agarose gel electrophoresis ( $1.5 \%$ agarose gel).

The PCR product was purified by Agencourt AMPure XP (Beckman Coulter, CA, USA), and then it was bidirectionally sequenced using BigDye ${ }^{\circledR}$ Terminator v.3.1 cycle sequencing kit (Applied Biosystems, Inc.) following the manufacturer's instructions. The obtained sequence electropherograms were edited manually. The sequences of amplified COI and 16S rRNA fragments were subjected to nucleotide BLASTn (Basic Local Alignment Search Tool) search in the NCBI GenBank to identify any closely related species. The COI and 16S rRNA sequences of abo (DDBJ accession numbers: LC594682 - LC594687) were aligned with similar sequences (Otolithes and Otolithoides) by Lakra et al. (2009) using the ClustalW program and then shortened to obtain the consensus length. Nucleotide differences of each sequence were counted, and Neighbor-joining (NJ) tree was constructed with the Kimura 2-Parameter model using the Molecular Evolutionary Genetics Analysis (MEGA7) (Kumar et al., 2015). Thunnus orientalis (GenBank Accession No. AB185022) was set as the outgroup species (Lakra et al., 2009). The bootstrap method with 2,000 replications was applied to test the robustness of topology nodes.

\subsection{Preliminary survey}

A preliminary survey was conducted to decide on the processing conditions required for the laboratory preparation of dried salted abo. Nine dried fish processors from the Calabanga fishing village in SMB were interviewed using a semi-structured survey questionnaire to document their existing process flows. Data from the survey revealed that dried abo processing involved submerging abo fillets in brine followed by sun -drying. Brining time practiced by the majority (78\%) of the processors was about 30 mins and the concentration of the brine ranged from $13.8 \%$ to $50 \%(\mathrm{w} / \mathrm{w})$. Including the fish weight, the brine concentration ranged from $7.0 \%$ to $12.5 \%(\mathrm{w} / \mathrm{w})$. Moreover, a majority $(55 \%)$ of the processors followed $12 \mathrm{hrs}$ of sun-drying, as the standard procedure.

\subsection{Dried fish processing}

For the dried fish processing, the abo fish purchased were placed immediately in an iced cooler box with the temperature kept low $\left(5 \pm 2^{\circ} \mathrm{C}\right)$, monitored using a THA02L digital temperature logger (As One, Japan) and then transported to the Fish Processing Laboratory of Partido State University, Sagñay, Camarines Sur, Philippines. The average weight and length of abo were $70.0 \pm 11.1 \mathrm{~g}$ and $20.0 \pm 1.06 \mathrm{~cm}$, respectively. Approximately $7 \mathrm{~kg}$ abo were divided into 6 groups. The collected abo samples were washed with tap water, degutted, split into butterfly fillet and soaked in a prepared brine solution $(4 \%, 8 \%$, and $12 \% \mathrm{w} / \mathrm{w}$ ) for 30 mins. Fish were then rinsed with tap water, placed in racks for sun-drying (for 6 and 12 hrs) and vacuum packed.

\subsection{Sample preparation for chemical analyses}

The dorsal part of dried fish muscle was used for all the chemical analyses (proximate analysis, salt content determination, protein profiling, and mass spectrometry). Sample preparation was done in an iced box to prevent the evaporation of moisture from samples. The head, bones, skin, and tail of the dried fish were removed. Collected flesh was cut into small pieces, homogenized with EG-45 electronic coffee mill (Kalita, Japan), and further pounded by a mortar and pestle. Samples were stored at $-20^{\circ} \mathrm{C}$ until analysis.

\subsection{Proximate analysis}

The commercial and laboratory-produced dried abo were subjected to proximate analyses. Proximate analyses for moisture, ash, crude protein, and crude lipid were carried out following the official methods described by the Association of Official Analytical Collaboration (AOAC) International (AOAC, 2000). Moisture was determined by oven-drying of samples at $105^{\circ} \mathrm{C}$ until constant weight. Ash was determined after combustion at $550^{\circ} \mathrm{C}$ in a muffle furnace for $18 \mathrm{hrs}$. Crude protein was calculated by multiplying the nitrogen content obtained by the micro-Kjeldahl method by 6.25 . Crude lipid was estimated by the Soxhlet extraction method.

\subsection{Salt content determination}

The salt content was determined by the conductivity of the solution using a PAL-SALT Probe digital salt 
meter (ATAGO CO. LTD., Japan). Approximately $1 \mathrm{~g}$ of sample was mixed with $4 \mathrm{~mL}$ distilled water, homogenized and centrifuged at $10^{\circ} \mathrm{C}, 2,147 \times g$ for 40 mins until the suspended matter was completely precipitated. About $2 \mathrm{~mL}$ of collected supernatant was transferred to the probe and analysed.

\subsection{Sodium Dodecyl Sulfate Polyacrylamide Gel Electrophoresis (SDS-PAGE)}

For fish myofibrillar protein extraction, about $50 \mathrm{mg}$ sample was homogenized with $1 \mathrm{~mL}$ buffer $(5 \% \mathrm{NaCl}$, $0.02 \mathrm{M}$ Tris-HCl, $\mathrm{pH} 7.2$ ) and $0.1 \%$ protease inhibitor cocktail (Nacalai Tesque, Inc., Japan). The supernatant was obtained by centrifugation at $0^{\circ} \mathrm{C}, 13,416 \times g$ for 20 mins. The protein concentration was determined by the Coomassie protein assay reagent kit (Thermo Fisher Scientific, USA) following the manufacturer's instructions.

A total of $5 \mu \mathrm{g}$ of protein were treated with the sample buffer solution with and without $2 \times 2$ Mercaptoethanol (2-ME; Nacalai Tesque, Inc., Japan) for SDS-PAGE and electrophoresed in $10 \%$ polyacrylamide gel by Tricine SDS-PAGE system (Schägger and von Jagow, 1987). The protein bands were stained with $0.04 \%$ Coomassie Brilliant Blue R-250 in 40\% methanol and $10 \%$ acetic acid and destained with $10 \%$ acetic acid.

\subsection{Protein identification by liquid chromatography- tandem mass spectrometry (LC-MS/MS)}

The protein was electrophoresed in a $10 \%$ SDSPAGE gel, and they were stained with SimplyBlue SafeStain (Invitrogen, USA) for $1 \mathrm{hr}$. After the excision of the targeted protein band, the gel was incubated in a de-staining solution $\left(50 \mathrm{mM} \quad \mathrm{NH}_{4} \mathrm{HCO}_{3}, \quad 50 \%\right.$ acetonitrile) for 10 mins at room temperature, and the destaining solution was replaced. This procedure was repeated until the gel was clear. The gel was then sequentially incubated with a reduction solution $(10 \mathrm{mM}$ dithiothreitol, $100 \mathrm{mM} \mathrm{NH} \mathrm{HCO}_{3}$ ) for $60 \mathrm{mins}$ at $56^{\circ} \mathrm{C}$ and an alkylating solution $(50 \mathrm{mM}$ iodoacetamide, 100 $\mathrm{mM} \mathrm{NH} \mathrm{NHCO}_{3}$ ) for 45 mins at room temperature in the dark. After reduction and alkylation of the protein, the

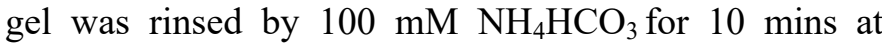
room temperature. The gel was vortexed in $100 \mathrm{mM}$ $\mathrm{NH}_{4} \mathrm{HCO}_{3}$ for 5 mins, and then again in acetonitrile for 5 mins before being dried by vacuum centrifugation. The dried gel was soaked in a digestion solution $(80 \mu \mathrm{L}$ of 10 ng $\mu \mathrm{L}-1$ trypsin gold, mass spectrometry grade, Promega, Madison, WI, USA: $50 \mathrm{mM} \mathrm{NH}_{4} \mathrm{HCO}_{3}$ ) on ice for 60 mins. The gel was then incubated overnight in 100 $\mathrm{mM} \mathrm{NH} \mathrm{NHCO}_{3}$ at $37^{\circ} \mathrm{C}$. The digested peptides were extracted by sonication in $50 \%$ acetonitrile and $70 \%$ acetonitrile in $0.1 \%$ trifluoroacetic acid. The sample was concentrated by vacuum centrifugation and suspended in $5 \%$ acetonitrile $-0.1 \%$ trifluoroacetic acid, then desalted using GL-Tips SDB (GL Sciences Inc.) and dried by vacuum centrifugation, and then dissolved in $5 \%$ acetonitrile $-0.1 \%$ trifluoroacetic acid. The sample was analysed using a Finnigan LTQ XL mass spectrometer (Thermo Fisher Scientific, Inc.), coupled with liquid chromatography (Michrom BioResources, Inc. AUBURN CA, USA) and equipped with a nanoelectrospray ion source (Thermo Fisher Scientific, Inc.). The MS/MS data were analysed with an in-house database by Mascot server, using Proteome Discoverer software version 1.2 (Thermo Fisher Scientific, Inc.).

\subsection{Statistical analysis}

The proximate analysis results and salt content are expressed as mean \pm standard deviation (SD) of three determinations. One-way analysis of variance (ANOVA) followed by Tukey's honest significance test (Tukey's HSD) was performed to determine the effect of salt concentration on proximate composition. All statistical analyses were tested at $p \leq 0.05$ significance level using $\mathrm{R}$ version 4.0.1 ( $\mathrm{R}$ Core Team, 2020).

\section{Results}

\subsection{Species identification}

Alignment of the COI and 16S rRNA sequences with their sequences from Otolithes and Otolithoides estimated a consensus length of $651 \mathrm{bp}$ and $571 \mathrm{bp}$, respectively. The COI sequences of all the three abos have a nucleotide identity of $100 \%$, whereas the nucleotide differences between abo and $O$. ruber sequences (EF534126) was estimated to be approximately $13.1 \%(85 / 651)$. The NJ tree-based on COI sequences produced two main groups (Figure 1a). Abo formed a separate subclade with the clustered $O$. ruber and Otolithes cuvieri with a 98\% bootstrap support, whereas the Otolithoides species formed a separate group.

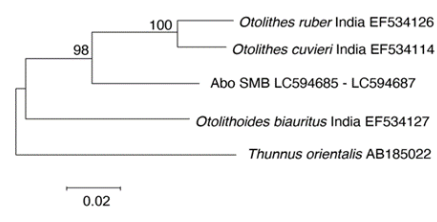

(a)

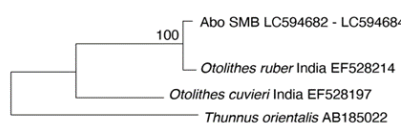

(b)
Figure 1. (a) NJ tree inferred from COI sequences (b) $\mathrm{NJ}$ tree inferred from $16 \mathrm{~S}$ rRNA sequences

All three 16S rRNA sequences of abo were completely the same (100\%). Only $0.9 \%$ nucleotide differences (5/571) were found among abo and $O$. ruber (EF528214) sequences. NJ tree clearly showed that abo is clustered with $O$. ruber with $100 \%$ bootstrap support (Figure 1b). 
Table 1. Proximate composition of dried abo samples prepared with various salt concentration and drying time

\begin{tabular}{cccccc}
\hline Drying Time (hr) & Salt Concentration (\%) & Moisture (\%) & Ash (\%) & Crude Protein (\%) & Crude Lipid (\%) \\
\hline 6 & 4 & $66.28 \pm 0.89^{\mathrm{A}}$ & $3.94 \pm 0.09^{\mathrm{A}}$ & $27.7 \pm 1.22^{\mathrm{AB}}$ & $0.52 \pm 0.03^{\mathrm{A}}$ \\
& 8 & $65.60 \pm 0.71^{\mathrm{A}}$ & $5.68 \pm 0.10^{\mathrm{B}}$ & $26.4 \pm 0.66^{\mathrm{A}}$ & $0.41 \pm 0.05^{\mathrm{A}}$ \\
& 12 & $58.61 \pm 1.91^{\mathrm{B}}$ & $8.67 \pm 0.37^{\mathrm{C}}$ & $29.2 \pm 0.68^{\mathrm{B}}$ & $0.71 \pm 0.23^{\mathrm{A}}$ \\
\hline \multirow{2}{*}{12} & 4 & $41.35 \pm 2.40^{\mathrm{a}}$ & $6.55 \pm 0.46^{\mathrm{a}}$ & $47.9 \pm 2.02^{\mathrm{a}}$ & $1.00 \pm 0.11^{\mathrm{a}}$ \\
& 8 & $42.98 \pm 1.63^{\mathrm{a}}$ & $9.59 \pm 0.27^{\mathrm{b}}$ & $45.5 \pm 2.81^{\mathrm{a}}$ & $0.94 \pm 0.33^{\mathrm{a}}$ \\
& 12 & $38.34 \pm 0.96^{\mathrm{a}}$ & $12.79 \pm 0.79^{\mathrm{c}}$ & $46.0 \pm 0.50^{\mathrm{a}}$ & $1.04 \pm 0.16^{\mathrm{a}}$ \\
\hline
\end{tabular}

Values are presented as mean, $\mathrm{n}=3$. Uppercase and lowercase letters denote samples dried for 6 hrs and 12 hrs, respectively. Values in the same column followed by the same superscript are not significantly different by Tukey’s HSD ( $\mathrm{p}>0.05$ ).

\subsection{Proximate composition and salt content}

Table 1 shows the proximate composition of abo samples at different salt concentrations and drying times. Moisture content ranged from 38.34-66.28\%. The moisture content of all samples significantly decreased with an increasing salt concentration in samples dried for $6 \mathrm{hrs}$. Maximum reduction was observed at $12 \mathrm{hrs}$ drying in $12 \%$ salt concentration (Table 1). The ash content ranged from $3.94-12.79 \%$ and was found to be increased with an increasing salt concentration in both $6 \mathrm{hrs}$ and 12 hrs drying time. Maximum ash content was estimated in samples dried for $12 \mathrm{hrs}$ with $12 \%$ salt. The crude protein content varied from 26.4-47.9\%. The salt concentrations did not reveal a significant effect in crude protein content except between $8 \%$ and $12 \%$ salt concentration samples at $6 \mathrm{hrs}$ drying time (Table 1). Similar effects were also observed for crude lipid content with no significant differences between the samples dried with different salt concentrations for both drying regimes. The salt contents of dried abo in $6 \mathrm{hrs}$ and 12 hrs drying ranged from $4.20-7.87 \%$ and $3.31-12.5 \%$, respectively (Table 2). It was found that the increasing salt concentration of the brine solution increased the salt concentration for both drying times, and the values of moisture, crude protein, ash, the crude lipid content of commercial dried abo were $37.72 \% \pm 0.61,50.7 \% \pm 0.47$, $9.56 \% \pm 0.09$ and $0.55 \% \pm 0.03$, respectively.

\subsection{Protein profile}

Seventeen bands of different molecular weights (MW) were detected (Figure 2). High intensity of protein bands with MW of $46 \mathrm{kDa}$ (band \# 7), $37 \mathrm{kDa}$ (band \# $10), 10 \mathrm{kDa}$ (band \# 16) and at the top of the gel (276 $\mathrm{kDa}$ ) were observed. In $12 \mathrm{hrs}$ drying (lanes 5 - 7), higher staining intensity was observed in MW of 276
$\mathrm{kDa}$ (band \# 1) while the bands at sizes of $136 \mathrm{kDa}$ (band \# 2), $58 \mathrm{kDa}$ (band \# 6), $43 \mathrm{kDa}$ (band \# 8), $33 \mathrm{kDa}$ (band \# 11), $25 \mathrm{kDa}$ (band \# 13) and $19 \mathrm{kDa}$ (band \# 14) revealed a lower intensity. However, at $6 \mathrm{hrs}$ drying (lanes $2-4$ ), staining intensity at MW of $276 \mathrm{kDa}$ (band \# 1) and $136 \mathrm{kDa}$ (band \# 2) were higher as compared to the bands at $73 \mathrm{kDa}$ (band \# 4), $58 \mathrm{kDa}$ (band \# 6), 43 $\mathrm{kDa}$ (band \# 8), $33 \mathrm{kDa}$ (band \# 11), $27 \mathrm{kDa}$ (band \# 12) and $19 \mathrm{kDa}$ (band \# 14). The protein profile of $12 \%$ salt concentration samples was different from $4 \%$ and $8 \%$ salt concentration samples (Figure 2).

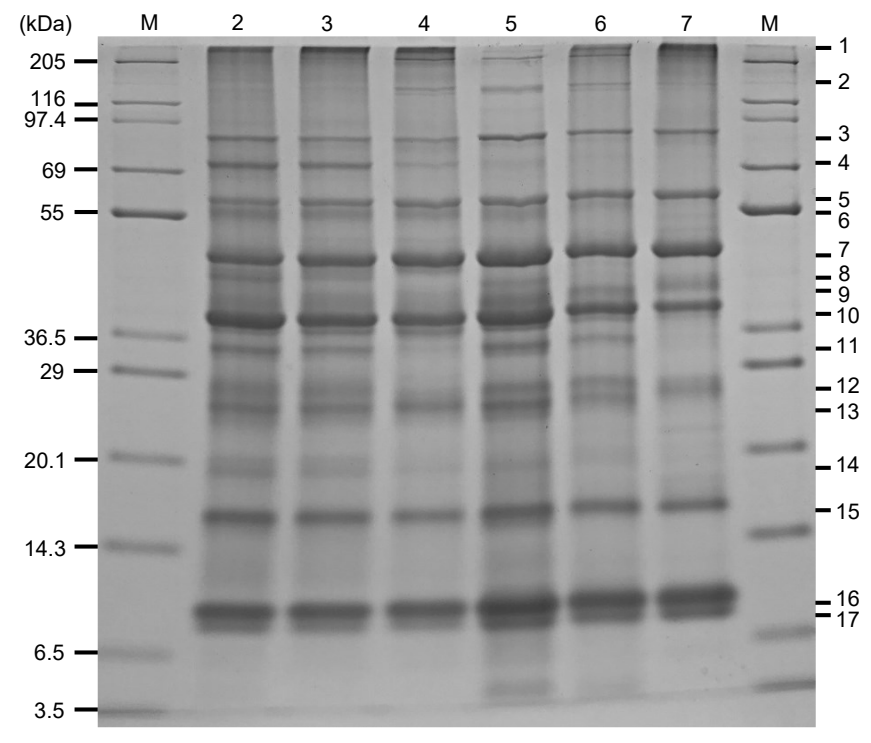

Figure 2. SDS-PAGE pattern of dried Abo with different salt concentration and drying time. Protein marker (lanes M); $4 \%$ salt concentration, 6 hrs (lane 2); $8 \%$ salt concentration, 6 hrs (lane 3); 12\% salt concentration, $6 \mathrm{hrs}$ (lane 4); 4\% salt concentration, 12 hrs (lane 5); $8 \%$ salt concentration, $12 \mathrm{hrs}$ (lane 6); $12 \%$ salt concentration, 12 hrs (lane 7)

\subsection{Mass spectrometry}

The identified protein in each band corresponds to

Table 2. Ash content and salt content of dried abo samples prepared with various salt concentrations and drying time

\begin{tabular}{cccc}
\hline Drying Time $(\mathrm{hr})$ & Salt Concentration $(\%)$ & Ash Content $(\mathrm{g} / 100 \mathrm{~g})$ & $\mathrm{NaCl}$ content by salt meter $(\mathrm{g} / 100 \mathrm{~g})$ \\
\hline 6 & 4 & $3.94 \pm 0.09$ & $4.20 \pm 0.27$ \\
& 8 & $5.68 \pm 0.10$ & $5.39 \pm 0.46$ \\
& 12 & $8.67 \pm 0.37$ & $7.87 \pm 0.80$ \\
\hline 12 & 4 & $6.55 \pm 0.46$ & $3.31 \pm 1.63$ \\
& 8 & $9.59 \pm 0.27$ & $9.33 \pm 0.43$ \\
& 12 & $12.8 \pm 0.79$ & $12.5 \pm 0.89$ \\
\hline
\end{tabular}


Table 3. Identified proteins from the dried abo muscle by LC-MS/MS

\begin{tabular}{ccl}
\hline Band & Estimated molecular weight* $(\mathrm{kDa})$ & \multicolumn{1}{c}{ Identified Protein } \\
\hline 1 & 276 & Actin, alpha skeletal muscle A \\
2 & 136 & Actin, alpha cardiac muscle 1 \\
3 & 86 & Tropomyosin alpha-1 chain \\
4 & 73 & Myosin heavy chain, fast skeletal muscle \\
5 & 61 & Myosin heavy chain, fast skeletal muscle \\
6 & 58 & Actin, alpha cardiac muscle 1 \\
7 & 46 & Beta-enolase \\
8 & 43 & Myosin heavy chain, fast skeletal muscle \\
9 & 39 & Tropomyosin alpha-1 chain \\
10 & 37 & Tropomyosin alpha-1 chain \\
11 & 33 & L-lactate dehydrogenase A chain \\
12 & 27 & Myosin heavy chain, fast skeletal muscle \\
13 & 25 & Triosephosphate isomerase B \\
14 & 19 & Myosin heavy chain, fast skeletal muscle \\
15 & 16 & Nucleoside diphosphate kinase B (Fragments) \\
16 & 10 & Parvalbumin, alpha \\
17 & 9 & Keratin, type I cytoskeletal 9 \\
\hline
\end{tabular}

*Estimated MW from SDS-PAGE analysis

the most abundant protein with the highest score for each band as analysed by the Proteome Discoverer 1.2 software (Table 3 and Figure 2). Among the 17 bands, 14 identified proteins were the same protein with the second -highest score (data not shown). The identified proteins included the fragments of myofibrillar proteins (bands 1 $-6,8-10,12,14)$ and sarcoplasmic proteins (bands 7 , $11,13,15-17)$.

\section{Discussion}

\subsection{Species identification}

Although a higher percentage of nucleotide differences (13.1\%) was observed in COI, the NJ tree indicated that abo formed a close phylogeny in the Otolithes clade ( $98 \%$ bootstrap support). The nucleotide differences and the $\mathrm{NJ}$ tree inferred from $\mathrm{COI}$ sequences demonstrated that abo might belong to the Otolithes genus. However, combining the obtained results of $\mathrm{COI}$ and $16 \mathrm{~S}$ rRNA confirms that abo in SMB is O. ruber.

\subsection{Proximate composition and salt content}

The moisture, crude protein, crude lipid, and ash content of the commercially available dried abo was almost similar to the values of proximate composition of samples dried at $12 \mathrm{hrs}$. This indicates that the obtained commercial dried abo is indeed processed with a longer drying time. In 6 hrs drying, moisture significantly reduced in $8 \%$ and $12 \%$ salt concentration samples. Although no significant difference was found among samples in $12 \mathrm{hrs}$ drying, reduction in moisture content was also observed. Similar to the results of our study, Hwang et al. (2012) found a significant decrease in moisture between $5-10 \%$ salt concentration samples of sun-dried milkfish. Lower moisture content in the $12 \%$ salt concentration samples can be attributed to the decrease in the water-holding capacity of proteins. Hamm (1960) suggested that at higher salt concentrations (approximately above $2 \mathrm{M}$ ), protein is denatured, resulting in cross-linking between proteins, increasing shrinkage and consequently loss of water from the muscle and, therefore, decreased the waterholding capacity. Hence, in the processing of dried salted abo, a salt concentration between $8-12 \%$ can be considered at $6 \mathrm{hrs}$ drying to improve the texture of the product.

Both ash and salt content increased as the salt concentration of the brine was increased, suggesting that ash was mainly derived from the added salt in the brine solution during processing. These results conform to the previous report by Hwang et al. (2012), in which the salt content of sun-dried milkfish increased with increased salt concentrations and was found significant between 5 $-10 \%$ salt concentrations. In contrast, the sodium chloride content of dried split fish products reported in the Philippine Food Composition Table ranged from $11.64-22.39 \%$ (DOST-FNRI, 2020). In this study, the $12 \%$ salt concentration samples have a salt content of $7.87 \%$ and $12.5 \%$ for $6 \mathrm{hrs}$ and $12 \mathrm{hrs}$ drying, respectively. This indicates that the dried abo samples contain lower salt content compared with the reported dried fish.

Crude protein content among samples of $12 \mathrm{hrs}$ drying time was not significantly different. However, in 6 hrs drying, the $12 \%$ salt concentration samples have significantly higher crude protein content than $4 \%$ and $8 \%$ salt concentration samples. Moreover, crude lipid values of dried abo were relatively low. This is similar to the lipid content of tigertooth croaker $O$. ruber in iced storage, which has been reported to be low as one of the characteristics of tropical fish species (Sharifian et al., 
2011). Low lipid content makes the muscle less susceptible to lipid oxidation; therefore, it could be advantageous for dried fish products in controlling the quality deterioration of the product.

\subsection{Protein profile}

SDS-PAGE electrophoretic patterns of $12 \mathrm{hrs}$ and 6 hrs dried samples have shown clear and defined bands. This could be attributed to the addition of protease inhibitors during extraction to minimize proteolysis. By LC-MS/MS, nine proteins were identified. The highintensity protein bands corresponded to tropomyosin (37 $\mathrm{kDa})$, actin (276 $\mathrm{kDa})$, beta-enolase (46 kDa), and parvalbumin $(10 \mathrm{kDa})$. Among these identified proteins, tropomyosin, beta-enolase, L-lactate dehydrogenase, triosephosphate isomerase, nucleoside diphosphate kinase, and parvalbumin were found stable in their native MW. On the contrary, myosin heavy chain, actin, and keratin had dissociated into fractions that were different from their theoretical MW. In both reducing (data not shown) and non-reducing SDS-PAGE conditions, the original MW of the myosin heavy chain $(200 \mathrm{kDa})$, actin $(43 \mathrm{kDa})$, and keratin $(62 \mathrm{kDa})$ were not observed. This could be due to the loss of moisture imposed by soaking in the brine solution and exposure to sun-drying resulting in the denaturation of proteins. It is also possible that during processing, these proteins could have been degraded by proteolytic enzymes. An earlier study has shown similar results that the endogenous enzymes such as cathepsins $\mathrm{B}, \mathrm{H}, \mathrm{K}$, and $\mathrm{D}$ during the processing of dried salted fish have contributed to the degradation of the fish protein ( $\mathrm{Wu}$ and $\mathrm{Cao}, 2018)$.

In the present study, changes in the protein profile were observed for both samples in $6 \mathrm{hrs}$ and $12 \mathrm{hrs}$ drying time. Among different salt concentrations in 12 hrs drying, similar band patterns were observed except for bands 1, 2, 6, 8, 11, 13 and 14. By mass spectrometry, these bands corresponded to actin (276 $\mathrm{kDa}$ and $136 \mathrm{kDa}$ ), MHC (43 kDa and $19 \mathrm{kDa}$ ), L-lactate dehydrogenase (33 kDa), and triosephosphate isomerase $(25 \mathrm{kDa})$. Between $8 \%$ and $12 \%$ salt concentration samples, the band intensity of actin $(276 \mathrm{kDa})$ had increased. On the contrary, decreased band intensities were observed in actin (136 kDa), MHC (43 kDa and 19 $\mathrm{kDa})$, and triosephosphate isomerase $(25 \mathrm{kDa})$. This indicates the occurrence of fragmentation of the myosin heavy chain and polymerization of actin. Moreover, at 6 hrs drying, similar band patterns were observed except for proteins identified as actin, MHC, and L-lactate dehydrogenase. In the $12 \%$ salt concentration samples, the band intensity of high-molecular-weight actin (276 $\mathrm{kDa}$ and $136 \mathrm{kDa}$ ) increased, whereas the intensity of actin with low-molecular-weight decreased (58 kDa), suggesting that actin might have polymerized. In the case of MHC fragments $(73 \mathrm{kDa}, 43 \mathrm{kDa}, 27 \mathrm{kDa}$, and 19 $\mathrm{kDa})$, band intensities markedly decreased. These observed changes were in contrast to the SDS-PAGE pattern of processed anchovies, which detected heavy band patterns tentatively identified as myosin and actin. The boiling process before drying the anchovies could have inactivated the proteases; thus, myosin and actin were still found intact and retained in their original MW (Dewi, 2002). In contrast, our present study was similar to the SDS-PAGE patterns of dried salted fish that have shown degradation of myofibrillar proteins influenced by different processing conditions. Thorarinsdottir et al. (2002) stated that myosin and actin were degraded to some extent during the salting of cod. In another previous study, intense aggregation of myofibrillar proteins, particularly myosin, as a consequence of the overall salting process of wet-salting followed by drysalting (Martìnez-Alvarez and Gómez-Guillén, 2006). Sannaveerappa et al. (2004) also found immediate loss of both high- and low-MW protein bands in dried milkfish due to the combined effects of salting and sun drying. Overall, this study demonstrated that myosin degradation and actin polymerization occurred in the abo muscle with the applied salting and drying time conditions.

\section{Conclusion}

This study was able to confirm the collected abo is Otolithes ruber through molecular identification. It also demonstrated that salt concentration and drying time influenced the proximate composition and protein profile of dried salted abo. Among different salt concentrations, the $12 \%$ samples have the highest reduction in moisture and the highest increase in crude protein and ash in both $6 \mathrm{hrs}$ and $12 \mathrm{hrs}$ drying time. Muscle proteins were greatly affected by processing as indicated by the degradation of myosin heavy chain and polymerization of actin which could affect the texture of the product. The findings of this study suggest that salt concentration can be controlled between $8-12 \%$ at 6 hrs drying, which could guide in formulating low salt and new texture of dried abo products.

\section{Conflict of interest}

The authors declare no conflict of interest.

\section{Acknowledgments}

This work was supported in part by the Ministry of Education, Culture, Sports, Science and Technology, Japan. We thank the Research Instrument and Radioisotope Research, Division of Biological Research, 
Science Research Center, Kochi University for the use of research instruments. We are also grateful for the support extended by Joshua M. Vacarizas, Bureau of Fisheries and Aquatic Resources (BFAR) ROV and the local government unit of Calabanga, Camarines Sur, Philippines.

\section{References}

Association of Official Analytical Chemists (AOAC). (2000). Official Methods of Analysis. 17th ed. Washington DC, USA: AOAC.

Bailey, C. (1982). Small-scale fisheries of San Miguel Bay, Philippines: occupational and geographic mobility. ICLARM Technical Reports 10, p. 1-6. Manila: Institute of Fisheries Development and Research, College of Fisheries, University of the Philippines in the Visayas, Quezon City, Philippines; International Center for Living Aquatic Resources Management, Manila, Philippines; and the United Nations University, Tokyo, Japan. Retrieved on August 30, 2018 from WorldFish Repository https:// digitalarchive.worldfishcenter.org/bitstream/ handle/20.500.12348/3561/Pub\%20TR4\%2010.pdf? sequence $=1 \&$ isAllowed $=y$

Bamwirire, D. (2006). Quality changes in salted, rehydrated and dry salted cod (Gadus morhua) products Iceland. Iceland: The United Nations University.

Batcagan-Abueg, A.D.M., Lee, J.J.M., Chan, P., Rebello, S.A. and Amarra, M.S.V. (2013). Salt intakes and salt reduction initiatives in Southeast Asia: A review. Asia Pacific Journal of Clinical Nutrition, 22(4), 683 -697. https://doi.org/10.6133/apjen.2013.22.4.04

DA-BFAR (Department of Agriculture - Bureau of Fisheries and Aquatic Resources) (2019). Philippine Fisheries Profile 2018. Manila, Philippines: DABFAR. https://www.bfar.da.gov.ph/publication.jsp? id $=2369 \#$ post

DOST-FNRI (Department of Science and Technology Food and Nutrition Research Institute). (2016a). Philippine Nutrition Facts and Figures 2015: Dietary Survey. Manila, Philippines: DOST-FNRI. http:// enutrition.fnri.dost.gov.ph/site/preview.php? $\mathrm{xx}=\%$ 20uploads/2015_DIETARY_SURVEY.pdf

DOST-FNRI (Department of Science and Technology Food and Nutrition Research Institute). (2016b). Philippine Nutrition Facts and Figures 2015: Clinical and Health Survey. Manila, Philippines: DOSTFNRI. http://enutrition.fnri.dost.gov.ph/site/ preview.php? $\mathrm{xx}=\%$ 20uploads/2015_CLINICAL_AND_HEALTH_SUR VEY.pdf
DOST-FNRI (Department of Science and Technology Food and Nutrition Research Institute). (2020). Philippine Food Composition (PhilFCT) Online Database. Retrieved on January 13, 2021 from iFNRI Website: https://i.fnri.dost.gov.ph/fct/library/ starting_pg

Dewi, E.N. (2002). Chemical analysis during the processing of dried salted anchovy. Journal of Coastal Development, 5(2), 55-65.

FAO (Fisheries and Agriculture Organization) (2019). FAO yearbook. Fishery and Aquaculture Statistics 2017. FAO, Rome. http://www.fao.org/3/ca5495t/ ca5495t.pdf

Gabriel, A.A. and Alano-Budiao, A.S. (2015). Microbial, physicochemical, and sensory quality evaluations of salted herring (Sardinella fimbriata) subjected to different drying processes. Food Science and Technology Research, 21(2), 213-221. https:// doi.org/10.3136/fstr.21.213

Hamm, R. (1960). Biochemistry of meat hydration. In Chichester, C.O., Mrak, E.M. and Stewart, G.F. (Eds). Advances in Food Research, Vol. 10, p. 355463. New York, USA: Academic Press Inc. https:// doi.org/10.1016/S0065-2628(08)60141-X

Hwang, C.C., Lin, M.C., Kung, H.S., Huang, Y.L., Hwang, D.F., Su, Y.C. and Tsai, Y.H. (2012). Effect of salt concentrations and drying methods on the quality and formation of histamine in dried milkfish (Chanos chanos). Food Chemistry, 135(2), 839-844. https://doi.org/10.1016/j.foodchem.2012.05.035

Islam, M.T., Ahmed, S., Sultana, M.A., Tumpa, A.S. and Flowra, F.A. (2013). Nutritional and food quality assessment of dried fishes in Singra Upazila under Natore district of Bangladesh. Trends in Fisheries Research, 2(1), 14-17.

Ito, N., Kitada, N., Yamada, N. and Seguin, M.L. (1990). Influence of dehydration temperature on change in myofibrillar protein of cured meat from walleye pollack. Nippon Suisan Gakkaishi, 56, 1647-1653. https://doi.org/10.2331/suisan.56.1647

Kumar, S., Stecher, G. and Tamura, K. (2016). MEGA7: Molecular Evolutionary Genetics Analysis version 7.0 for bigger datasets. Molecular Biology and Evolution, 33(7), 1870-1874. https://doi.org/10.1093/ molbev/msw054

Lakra, W.Z., Goswami M. and Gopalakrishnan, A. (2009). Molecular identification and phylogenetic relationships of seven Indian Sciaenids (Pisces: Perciformes, Sciaenidae) based on 16S rRNA and cytochrome c oxidase subunit I mitochondrial genes. Molecular Biology Reports, 36(5), 831-839. https:// doi.org/10.1007/s11033-008-9252-1 
Lanzuela, N., Gallego, E. and Baltar, J.E. (2020). Reproductive Biological Performance of Otolithes ruber (Bloch and Schneider 1801) in San Miguel Bay, Philippines. The Philippine Journal of Fisheries, 27(2), 1-10. https://doi.org/10.31398/ tpjf/27.2.2019C0006

Lasco, G., Mendoza, J., Renedo, A., Seguin, M.L., Palafox, B., Palileo-Villanueva, L.M., Amit, A.M.L., Dans, A.L., Balabanova, D. and McKee, M. (2020). Nasa dugo ('It's in the blood'): lay conceptions of hypertension in the Philippines. BMJ Global Health, 5(7), e002295. https://doi.org/10.1136/bmjgh-2020002295

Lee, N.R. (2009). Estimating the effects of overweight duration, sodium intake and genetic variants on hypertension risk among Filipino women in Cebu, Philippines. North Carolina, USA: The University of North Carolina at Chapel Hill, PhD. Dissertation.

Lim, C.P., Matsuda, Y. and Shigemi, Y. (1995). Problems and Constraints in Philippine Municipal Fisheries: The Case of San Miguel Bay, Camarines Sur. Environmental Management, 19(6), 837-852. https://doi.org/10.1007/BF02471936

Lo, P.C., Liu, S.H., Nor, S.A.M. and Chen, W.J. (2017). Molecular exploration of hidden diversity in the Indo -West Pacific sciaenid clade. PLoS ONE, 12(4), e0176623. https://doi.org/10.1371/journal. pone. 0176623

Martìnez-Alvarez, O. and Gómez-Guillén, M.C. (2006). Effect of brine salting at different $\mathrm{pHs}$ on the functional properties of cod muscle proteins after subsequent dry salting. Food Chemistry, 94(1), 123129. https://doi.org/10.1016/j.foodchem.2004.11.001

Mines, A.A., Pauly, D., Navaluna, N.A. and Vakily, J.M. (1982). The physical environment. In Pauly, D. and Mines A.N. (Eds). Small-scale fisheries of San Miguel Bay, Philippines: biology and stock assessment. ICLARM Technical Reports 7, p. 5-14. Manila: Institute of Fisheries Development and Research, College of Fisheries, University of the Philippines in the Visayas, Quezon City, Philippines; International Center for Living Aquatic Resources Management, Manila, Philippines; and the United Nations University, Tokyo, Japan. Retrieved on August 30, 2018 from World Fish Repository https:// digitalarchive.worldfishcenter.org/bitstream/ handle/20.500.12348/3563/Pub\%20TR4\%207.pdf? sequence $=1$

Msusa, N., Likongwe, J., Kapute, F., Mtethiwa, A. and Sikawa, D. (2017). Effect of processing method on proximate composition of gutted fresh Mcheni (Rhamphochromis species) (Pisces: Cichlidae) from Lake Malawi. International Food Research Journal,
24(4), $\quad 1513-1518$. ija.2016.06.0018

https://doi.org/10.5376/

Navaluna, N.A. (1982). Morphometrics, Biology and Population Dynamics of the Croaker Fish, Otolithes ruber. In Pauly, D. and Mines, A.N. (Eds). Smallscale fisheries of San Miguel Bay, Philippines: biology and stock assessment. ICLARM Technical Reports 7, p. 38-55. Manila: Institute of Fisheries Development and Research, College of Fisheries, University of the Philippines in the Visayas, Quezon City, Philippines; International Center for Living Aquatic Resources Management, Manila, Philippines; and the United Nations University, Tokyo, Japan. Retrieved on August 30, 2018 from WorldFish Repository https:// digitalarchive.worldfishcenter.org/bitstream/ handle/20.500.12348/3563/Pub\%20TR4\%207.pdf? sequence $=1$

Offer, G. and Trinick, J. (1983). On the mechanism of water holding in meat: The swelling and shrinking of myofibrils. Meat Science, 8(4), 245-381. https:// doi.org/10.1016/0309-1740(83)90013-X

Palumbi, S., Martin, A., McMillan, W.O., Stice, L. and Grabowski, G. (2002). The simple fool's guide to PCR. Version 2.0. Honolulu, HI: Department of Zoology and Kewalo Marine Laboratory, University of Hawaii.

Patterson, J., Kailasam, S. and Immaculate, J.K. (2018). Effect of drying technologies on the biochemical properties of Stolephorus commersonnii. Food Quality and Safety, 2(3), 153-158. https:// doi.org/10.1093/fqsafe/fyy010

Pomeroy, R.S. and Pido, M.D. (1995). Initiatives towards fisheries co-management in the Philippines: The case of San Miguel Bay. Marine Policy, 19(3), 213-226. https://doi.org/10.1016/0308-597X(94) 00008-G

R Core Team. (2020). R: A language and environment for statistical computing. R Foundation for Statistical Computing, Vienna, Austria. Retrieved on June 6, 2020 from https://www.R-project.org/

Sannaveerappa, T., Ammu, K. and Joseph, J. (2004). Protein-related changes during salting of milkfish (Chanos chanos). Journal of Science of Food and Agriculture, 84(8), 863-869. https://doi.org/10.1002/ jsfa.1682

Schägger, H. and von Jagow, G. (1987). Tricine-sodium dodecyl sulfate-polyacrylamide gel electrophoresis for the separation of proteins in the range from 1 to 100 kDa. Analytical Biochemistry, 166(2), 368-379. https://doi.org/10.1016/0003-2697(87)90587-2

Sharifian, S., Zakipour, E., Mortazavi, M.S. and Arshadi, 
A. (2011). Quality assessment of tiger tooth croaker (Otolithes ruber) during ice storage. International Journal of Food Properties, 14(2), 309-318. https:// doi.org/10.1080/10942910903177822

Silvestre, G.T. and Hilomen, V.V. (2004). Status of Fisheries in San Miguel Bay. In Department of Agriculture-Bureau of Fisheries and Aquatic Resources (DA-BFAR) (Eds). In turbulent seas: The status of Philippine marine fisheries. Coastal Resource Management Project of the Department of Environment and Natural Resources, p. 292-299. Cebu City, Philippines: DA-BFAR.

Tambo, T., Yamada, N. and Kitada, N. (1992). Change in myofibrillar protein of cured horse mackerel meat induced by dehydration. Nippon Suisan Gakkaishi, 58(4), 685-691. https://doi.org/10.2331/ suisan. 58.685

Thorarinsdottir, K.A., Arason, S., Geirsdottir, M., Bogason, S.G. and Kristbergsson, K. (2002). Changes in myofibrillar proteins during processing of salted cod (Gadus morhua) as determined by electrophoresis and differential scanning calorimetry. Food Chemistry, 77(3), 377-385. https:// doi.org/10.1016/S0308-8146(01)00349-1

Ward, R.D., Zemlak, T.S., Innes, B.H., Last, P.R. and Herbert, P.D.N. (2005). DNA barcoding Australia's fish species. Philosophical Transactions of the Royal Society B, 360(1462), 1847-1857. https:// doi.org/10.1098/rstb.2005.1716

Wu, Y. and Cao, S.M. (2018). Study on endogenous protease and protein degradation of dry-salted Decapterus maruadsi. CyTA - Journal of Food, 16 (1), 350-356. https:// doi.org/10.1080/19476337.2017.1406006

Yater, F., Esporlas, A.E. and Smith, I.R. (1982). Economic aspects of processing and marketing. In Smith, I.R. and Mines, A.N. (Eds). Small-scale fisheries of San Miguel Bay, Philippines: economics of production and marketing. ICLARM Technical Reports 8, p 104-124. Manila: Institute of Fisheries Development and Research, College of Fisheries, University of the Philippines in the Visayas, Quezon City, Philippines; International Center for Living Aquatic Resources Management, Manila, Philippines; and the United Nations University, Tokyo, Japan. Retrieved on February 17, 2020 from WorldFish Repository https:// digitalarchive.worldfishcenter.org/bitstream/ handle/20.500.12348/3544/WF_2003.pdf? sequence $=1 \&$ is Allowed $=\mathrm{y}$ 